\title{
Globalization and Income Gap from the Perspective of Developing Countries
}

\author{
NING Guang-jie \\ (School of Economics, Nankai University, Tianjin 300071, China)
}

\begin{abstract}
Using political economic theory, this paper analyzes the impact of economic globalization on international income distribution, including the income gap between developed countries and developing ones, the income gap among the developing countries. The paper states that because the economic globalization is the globalization of capitalism manufacture style and developed countries dominates the process, the income gap between developing countries and developed one is difficult to be narrowed, and the income gap in developing countries will enlarge.
\end{abstract}

Key words: economic globalization; income gap; labor productivity; labor standard; unequal exchange

The claim to deepen globalization has become extremely higher since 1990s. With the tremendous rise in international trade and transnational corporation's FDI allocating the resource in the scope of all around the world, profound and long-lasting impacts are exerted on the developing countries, among which the income distribution is an important issue. It concerns not only the income gap between developed countries and developing countries, but the one in the inner of developing countries. The advocate of comparative advantage theory and economic growth theory all insist that the income gap will be narrowed. However the fact is that the income gap has been enlarged with the trend of globalization. Responding to this problem, interprets range from the low quality of human capital in developing countries that cannot benefit greatly from the technology spill-out, to the changing technological and industry structure with the pace of globalization. The existing explanations are not sufficient however.

This paper tries to analyze various factors that influence the labor wage in developing counties. It states that the poor productivity of labors is related to the secretly technology application in the transnational, and the wage is also influenced by the unequal exchange in the international goods market, which result in the wage gap between developing countries and developed countries. In addition, the monopsony of labor market, the low level of trade union organization rate and the segmented labor market all depressed the wage. In the inner of developing countries, some are benefited from the inflow of foreign capital owing to their close social and economic link. Their personal wealth increased by employing a large number of workers. Under the framework of international system, labors in developing countries are now been exploited by the world capitalist, their status cannot be improved as long as the capital accumulating effect dominated. In this paper, we take China as an example to illustrate why the income gap is enlarged with the economy openness deepened.

\section{The Income Gap between Developed Countries and Developing Countries}

NING Guang-jie, associate professor of School of Economics, Nankai University; research fields: labor economics, political economy. 
The theoretical foundation of narrowing income gap lies in the diminishing marginal revenue. According to this theory, the countries with less capital can catch up with the developed counties. The new economy growth theory emphasized the issue of increasing return. They asserted that the convergence will not happen or will happen only under some specific condition. But they only search for the reasons in the areas such as human capital or technology diffusion. Other vital reasons are ignored.

The free inflow and outflow of factors will contribute to the convergence of factor price. Even though the tendency of equalizing the profit rate can be seen in the world capital market, there is no evidence of wage convergence. Someone stated that there were some barriers restricting labor's free mobility all over the world. However, if the capital can move freely, the production factory can be founded in suitable location, there is no need for the labor to move. In other words, as long as there exists capital's free mobility, investment competition can realize the wage convergence. Wage convergence without the labor mobility can be anticipated.

Consequently we have to study the problem in an alternative perspective. The investment in developing countries made by developed countries take full use of the cheap labor, meanwhile the labor's productivity is not low compared with the low wage. The labor's productivity is also influenced by the technology adopted by the investor. The positive impact of technology transfer is much more limited than people normally considered. Many transnational corporations only view the firm founded in developing countries as a manufacture center, transferring technology does not often happen. The labor's productivity in developing countries is not comparable with their counterparts' in developed countries. But even in that case, considering the low wage, labor's productivity in developing countries is relatively high.

The wage is greatly reduced in the circumstance of labor monopsony. There are limited job opportunities in less developed countries, compared with large amount of surplus labors. The location the foreign investor selected is endowed with cheap labor. It is often the case that a foreign company is the sole buyer of labor in an area, which endows the buyer monopsony status. Once the labor is employed, he cannot leave the company even though there were some alternative job opportunities until the labor contract expires. The segmented labor market in developing countries also made the labor less easily mobile. As a result, the employer can pay the labor a lower wage according to the supply curve. Unlike the wage determined by the supply curve and demand curve of labor in the competitive market, in the monpsony case however, the wage is determined by the employer solely. The wage and the number of employment is less than those in the competitive case.

The fact that the trade union in developing counties is less organized makes the labor's welfare cannot improve fully. In a joint venture or foreign investment company, trade union seldom exists. Even though there is some one, its role often cannot be played fully. Faced with foreign employer, trade union often has no efficient way to communicate with the employer, not to say how to bargain with him.

Basically, according to the neoclassical income distribution theory, the labor's wage equals his marginal product multiplied by the price of product. If the wage is less than that, then the worker will be exploited. The meaning of exploitation here differs from Marx's concept of exploitation. However, even in the narrow meaning of new classical school's exploitation concept, there are strong evidences that workers are less paid owing to monopsony and the relatively weakness of trade union.

The Nike sports shoes company in Indonesia is often accused of its low working payment and hard working condition. The average salary is only $\$ 35$ per month, just above the minimum wage set by the local government. The workers have to work for 60 hours per week, while the earning can hardly afford for basic subsistence items.

The capitalism production center is shifted to developing countries, making more and more poor labors force 
to join the production system. The capitalism enterprises try to seek suitable investment places (relatively lower cost, more profit) to solidify and sustain the capital production structure. They are unsatisfied with exploiting the workers in their motherland where the labor cost is relatively high. By contrast, in developing countries large quantities of labors are starving for their "kind" offering a job. Exploiting the abundant labor in developing countries is a new profitable venture, at least in a relative not short time. The power of capital revived and expanded in the age of globalization.

The capital's global movement can also be explained by the Long Wave Theory. It is often stated that capitalist economy experienced the downward stage in the 1970s as a result of the erosion of capitalist institutional conditions. The possible solution to this crisis will be the globalization of capitalist production system. Consequently, the long wave can rise to expansion in a broader environment and the inherent instabilities of capitalism economy are temporarily overcome.

The capitalist can shed the controversy and struggles to break out frequently in their motherland, and select a favorable labor relation environment to continue their profit-seeking venture. It is true that the problem of labor relation is often ignored in the circumstance of encouraging foreign investment in developing countries. Whereas in their motherland the relationship between workers and capitalist experiences a long history of a few centuries, accumulating lots of disagreement and controversy. In developing counties, the capitalist production system seems to the local government and workers as a new and welcoming model. They desired it to bring forth good luck and prosperity, willing to endure some disagreeableness at least in short run.

According to the neoclassical distribution theory, another factor influence the wage is the price of product. Whether the product manufactured in developing countries can earn a fair price or not will determine the income level of labor. But the main lines of export goods coming from developing countries are resource or energy product, whose price is often been undervalued. In other words, there exists unequal exchange in international trade market. It is the manufacturer that determines the fate of the export price. If the manufacturer comes from developed country, the price will not be lowed. Moreover, there exists a dilemma: the product will not be sellable without a low price, however the developing countries are often been accused of dumping through low price. The frequent broken out trade frictions lead to the fluctuation of labor wage.

The relatively low wage lead to cheap price of export product, which makes the product made in developing countries competitive in the world market. This annoyed the competitor in developed countries, not only the employer but the workers as well asserted that the low wage in developing countries should be raised. Of course, it is not because workers in developed countries have compassion on their counterparts in developing countries. What they concern seriously about is to raise their competitor's cost. From the prospect of developing countries, they insisted that the welfare in developing country is incomparable with that in developed country. They have no ability to give worker's wage such a huge increase, stating that the raised cost will ruin their economic development process. The wage should be determined in the market, not relying on the developed countries' labor standard. However, it is not because the employer has no ability to afford higher wage, but because they take advantage of the environment in developing countries to seek more profit at the cost of the labors. The status can never equal so long as working is the labor's only choice, his tool for living.

Now that the income gap between developing country and developed countries exists, the labor mobility across country can alleviate the situation. However there are strict barriers to free labor mobility. In quite a few advanced countries witnessed the anti-immigrant wave.

In conclusion, workers in developing countries are suffered from exploitation by the international capitalists. 
Their wage and income is reduced to a low subsistence level, which make the income gap between developing country and developed countries persists.

\section{The Income Gap in Developing Country}

The income gap is enlarged in developing country with the trend of globalization. Why globalization brought forth different benefit to different class?

The severe condition of income gap in developing country is related to the development phase suggested by the adverse U-shape curve of Kuznets? But the development phase cannot interpret the income gap sufficiently. The income gap is closely related to changes in class structure, which dated back to colonial time. The history of colonialism changes the class structure in developing countries (Wolff, 2001), and the enterprises benefited from the colonialism made a fortune and become the dominating class. In the new era, the old colonialism revived in a new fashion.

The process of globalization is also characterized by the widespread of neo-liberalism thought. Only the production system over the world is dominated by the capitalist class relation, can the capitalist globalization proceed and run smoothly. A dramatic extension of capitalist relations of production has happened in Eastern Europe and China since 1980s. Influenced by the invading neo-liberalism ideas, great changes in ideology and legislation have taken place. It should be stressed that the new market economy differs from the counterparts in developed countries, which is beyond the control of government regulation. Due to the lack of proper redistribution and regulation policy, the mounting numbers of private enterprises and foreign enterprises had a greater adverse impact on the income distribution gap.

Firstly, the new globalization changed the class structure of developing countries. With the entry of foreign companies, the capitalism production structure is deeply rooted and the scope of capitalism production structure is extended and broadened. State-owned enterprises were defeated by the foreign competitors and the workers losing their jobs have to find a new one in foreign investment company. Many a companies offer a relatively high salary to some talented and skilled workers in order to attract employees with high quality, some of which are even prompted to a high position. But the majority of employees are less paid in line with their productivity. The relatively high salary wage earned in foreign country make someone a new class in developing countries. They are richer than ordinary resident, accordingly showing favorable attitude toward foreign investment. There are private enterprises benefited from the invading of foreign investment because of the links between their production systems. These employers allied with the white collar in foreign companies consist of the dominating class in developing countries, worsening the situation of the income gap.

Secondly, according to the traditional theory, with the great innovation of industry structure, there are increasing demand for high skilled labor, meanwhile the demand for less skilled labors are significantly decreased. Consequently, the wage for high-skilled labor is raised to a high level, making the income gap unable to be narrowed. However it is not often the case in the developing countries. Foreign investors taking advantage of cheap labor show little interest in promoting and adopting technology. It is well known that appropriate on-the-job training can contribute to worker's acquiring new skill. However the less-skilled workers have less access to training program in developing countries, which made them difficult to improve their disadvantage situation. The training program provided by foreign investors is not frequently seen. On the contrary, they often dig skilled workers from state-owned enterprises by attractive salary. In this way, they can save the high training expense. As 
long as the enterprise provided training program is postponed and cannot keep concordance with the development of industry structure, the problem of mismatch and great income gap will be persistent. The monopsony enterprises even underpay the unskilled labors and wish the cheap labor advantage to be permanent, the developing countries acting as the manufacturing factory of international capitalism production.

Finally, the segmented labor market also exacerbates the income improvement of disadvantaged people. There are some barriers and restriction set up by the government to free mobility, the aim of which is to mitigate the pressure of over-urbanization, reducing some adverse impacts associated with the labor mobility. This can be called some monopoly or rent set by the government. The extreme form of segmented labor market is the dual-labor market, which is under detailed discussion by economists. The worker in primary labor market earn a relatively high wage, enjoying a stable employment prospect, whereas the workers in the secondary labor market can only earn low wage and have a high risk of being fired. For example, in China, different region have different open policy. The region enjoying most favorable policy becomes the primary labor market and its workers can benefits greatly from this environment. It should be noted that the dual labor market result not only from the intervention of government, but also from the monopoly status earned by big enterprises in product market.

It is stated that the benefits of China's open policy should be redistributed (WANG Shao-guang, 2002). However the class structure is not easy to be changed once formed. The redistribution will not be feasible with the prevailing class structure unaltered.

\section{The Income Distribution in the Framework of World System}

Core country and periphery country locate in different part in world manufacture system and appropriate different value from it, which has no inevitable connection with the labor division. Core country refers to developed countries and periphery country corresponds to developing countries. Now let us take an example of terrestrial globe for children study to illustrate how the value is distributed in different processes of manufacturing and sale.

Table 1 Children study used terrestrial globe goods links and value distribution

\begin{tabular}{cccc}
\hline Goods links & $\begin{array}{c}\text { Sale price at the } \\
\text { bottom of link(\$) }\end{array}$ & $\begin{array}{c}\text { Added value realized } \\
\text { in the link(\$) }\end{array}$ & $\begin{array}{c}\text { The proportion of } \\
\text { total added value(\%) }\end{array}$ \\
\hline American retailer & 88 & 16 & 32 \\
American manufacturing corp.-> & 72 & 20 & 42.1 \\
Hong Kong trade corp.-> & 40 & 5 & 26.3 \\
Guangdong trade corp.-> & 20 & 3 & 3.9 \\
Production firms in Jiangsu and Guangdong & 15 & 1 & $/$ \\
\hline
\end{tabular}

Notes: -> represents ordering goods from the following links.

Data source: LI Min-qi. China Social Structure in the Vision of World System. Horizon, 2001, 11(8): 8.

It can be found in Table 1 that production firms in China earns only 3.9\% of the total value added, the trade firms in China earns 6.6\%. The price can be raised at a higher extent after the link of Hong Kong trade corporation, which rests on the fact of China mainland firm's low price. It is unequal in the process of value distribution that developed countries gain a larger proportion. As the periphery of international capitalism, China mainland's gain account to $10.5 \%$. Hong Kong earned $26.3 \%$ as the quasi-core region and U.S. appropriated $63.2 \%$ as a core country. This is a typical case, which conforms to the global goods link law. Accordingly, the income gap among 
different countries is inevitable.

If the manufacturer in China is the foreign investor, can things be different? Can they accept and tolerate the less distributed value? The entry of foreign investors does not guarantee that they will help developing countries earn more proportion of value. However it does not mean that they will earn less amount of profit either, as all the added value will be obtained by the investor solely ${ }^{1}$. By contrast, in other links, the relatively higher added value will be shared between the firms and workers. Owing to the capital flow, the profit rate has the tendency of equalization. Foreign investors in developing countries can earn the comparable and considerable profit rate from the lower proportion of added value, just because the manufacture cost is depressed and the wage is depressed. Alternatively, only the developing countries' wage is deeply lower than their counterparts in developed countries, can the core country obtain the greater part of the value.

The fact is that wage gap is obvious among the world system. Taken the monthly average wage of manufacture industry in U. S. as 100 , Korean's wage rate is 77 , Israel is 72.8 , Singapore is 68.8 , Hong Kong is 48.7. These countries belong to quasi-core countries and their wage level accounts for core countries' $50 \%-75 \%$. Argentina's wage level is $34.2 \%$ of American's, Brazil is $24.9 \%$, Chile is $18.1 \%$, Hungary is $14.2 \%$, Poland is $12.6 \%$, Czech is $11.6 \%$, Thailand is $11.3 \%$, all these countries belong to half-periphery countries. Their wage level is $10 \%-30 \%$ of core countries' wage. Turkey's wage is $8.8 \%$ of American's, Mexico is $8.6 \%$, Russia is $6.5 \%$, China is $2.3 \%$, India is $1.7 \%$, and these countries belong to periphery countries. Their wage level stands for core countries' only $1 / 20-1 / 50^{2}$. The unequal state can be seen clearly in the pyramid shape distribution: a limited rich country in the upper level; many periphery countries having large amounts of poor people in the lower level, whereas the quasi-core countries and half periphery countries lies in between. Attempts to narrow or erase the income gap seem to be futile, as the capitalism dooms to bring out the economy imbalance. Imbalance development is the characteristic of capitalism.

Under the framework of world system, how is the income distribution condition evolving in the core and periphery countries? They are also dominated by the global capital accumulation structure. We can analyze the problem by comparing the class structure of different countries.

Table 2 Class structure comparison of core, half periphery and periphery countries

\begin{tabular}{cccc}
\multicolumn{4}{c}{ ( percent of economic activity population) } \\
\hline Class & $\begin{array}{c}\text { Core country } \\
\text { (U.S. 1990) }\end{array}$ & $\begin{array}{c}\text { Half Periphery } \\
\text { (Latin American1990/1992) }\end{array}$ & $\begin{array}{c}\text { Periphery } \\
\text { (China 1999) }\end{array}$ \\
\hline State and social manager & $/$ & $/$ & 2 \\
Capitalist class & 5 & $2-4$ & 1 \\
Middle class & 20 & $10-15$ & 11 \\
Petty bourgeoisie & 5 & $9-17$ & 4 \\
Proletariat & 45 & $18-28$ & $<23$ \\
Half proletariat & 25 & $32-47$ & $>25$ \\
Peasant & $/$ & $5-12$ & 44 \\
\hline
\end{tabular}

Data source: LI Min-qi. China Social Structure in the Vision of World System. Horizon, 2003, 11(8): 15.

Firstly, even as a core country, the U. S. is a proletariat mass country. The proletariat class accounts for nearly half of the total population, while the proletariat and half proletariat (having no formal job, employed in the

\footnotetext{
${ }^{1}$ The wage is included in the cost.

2 LI Min-qi. China Social Structure in the Vision of World System. Horizon, 2001, 11(8): 9-10.
} 
informal sector in suburb or surplus labor flowing between city and countryside) amount to $70 \%$. $90 \%$ of the people have to support themselves by selling their labor force to earn wage. Capitalist class and petty bourgeoisie stand for only $10 \%$, yet they employed nearly $90 \%$ of the population to create surplus value for them, which is the root reason for income gap. The middle class can enjoy a relatively high wage, but their proportion in the population is small. Middle class act as the stabilization role in capitalist economy. The capitalist buy the middle class over to support the system by offering them high wages. The "loyalty rent" is doomed to aim at a relatively small group. For the cost will tremendously rise with the scope of buying over enlarging. Furthermore, the effect will be diminishing with the scope extending, as high wage will not be the privilege of small group any longer.

Secondly, in the half-periphery counties represented by Latin American, the ratio of capitalist class is higher than that of central countries, but most of them are petty bourgeoisie, which is the proof of their capitalist economy being less developed. Although the capitalist class ratio is low, they control most of the national income, whereas the proletariat and half proletariat account for $50 \%-75 \%$ of population, as a result, the income gap is even deteriorated in Latin American. Among the working class, the ratio of middle class is lower (only 10\%-15\%) and the ratio of proletariat is lower too. The proportion of half proletariat is higher and peasant also accounts for some proportion. This is another characteristic differing from central countries, which also determines the larger income gap among the working class of half periphery country. Half proletariat and peasant is the class who lacks bargaining power, their income and economic status are even lower than that of proletariat.

Finally, as a periphery country, the ratio of capitalist class in china is not high, but is growing. The proportion of proletariat is relatively low. Half proletariat is increasing, many of whom are converted from proletariat. For instance, state-owned enterprises collapsed owing to the entry of foreign companies, the former workers were laid off and become employed in the informal sector. The proportion of peasant is still large, but is falling continuously. The peasant will firstly become half proletariat, and then could become proletariat. The peasant and half proletariat is low wage class, their big share in the population proportion determines the seriousness of income inequality.

It can be said that the class structure in central and periphery countries is influenced by the economic globalization. For example, the multinationals of advanced countries' global investment enrich the capitalist class. The multinationals defeated the previous protected industry of periphery countries and made quantities of proletariat half proletariat, accordingly change the class structure of periphery countries. Class structure determines the situation of income distribution. The income distribution of central and periphery countries is therefore influenced by the economic globalization.

If the class structure wants to be improved, apart from the tax adjustment implemented in domestic, can the periphery countries resort to economic globalization? The answer seems to be yes. Only the developing countries take activity in the globalization process, trying to occupy the favorable position and earn a greater share in the value link, can the labor's wage be raised? However, is this prospect hopeful? If the labor's wage is raised and the periphery countries step into the line of half periphery countries, the global capitalist will lose large amounts of cheap labors unless there are some other new periphery countries to replace the old one. The existing periphery countries income gap will not be easy to be alleviated by the globalization. The core-periphery structure will sustain in the process of globalization. It is true that some lucky periphery one like the Four Little Dragons of Asia changed their fate eventually, but it exerted little impact on the whole global distribution situation.

(to be continued on Page 18) 